\title{
NREL Small Wind Turbine Test Project: Mariah Power's Windspire Wind Turbine Test Chronology
}

Technical Report NREL/TP-500-45552 June 2009

A. Huskey and T. Forsyth 


\title{
NREL Small Wind Turbine Test Project: Mariah Power's Windspire Wind Turbine Test Chronology
}

\author{
A. Huskey and T. Forsyth
}

Prepared under Task No. WER9.4501

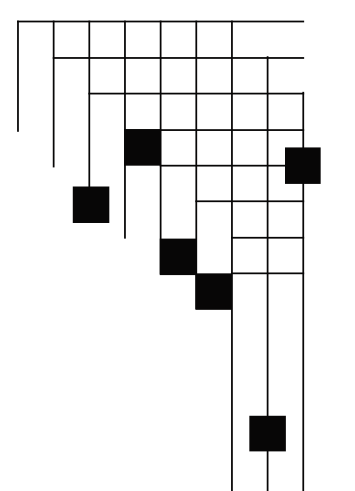




\section{NOTICE}

This report was prepared as an account of work sponsored by an agency of the United States government. Neither the United States government nor any agency thereof, nor any of their employees, makes any warranty, express or implied, or assumes any legal liability or responsibility for the accuracy, completeness, or usefulness of any information, apparatus, product, or process disclosed, or represents that its use would not infringe privately owned rights. Reference herein to any specific commercial product, process, or service by trade name, trademark, manufacturer, or otherwise does not necessarily constitute or imply its endorsement, recommendation, or favoring by the United States government or any agency thereof. The views and opinions of authors expressed herein do not necessarily state or reflect those of the United States government or any agency thereof.

Available electronically at http://www.osti.gov/bridge

Available for a processing fee to U.S. Department of Energy and its contractors, in paper, from:

U.S. Department of Energy

Office of Scientific and Technical Information

P.O. Box 62

Oak Ridge, TN 37831-0062

phone: 865.576 .8401

fax: 865.576 .5728

email: mailto:reports@adonis.osti.gov

Available for sale to the public, in paper, from:

U.S. Department of Commerce

National Technical Information Service

5285 Port Royal Road

Springfield, VA 22161

phone: 800.553.6847

fax: 703.605.6900

email: orders@ntis.fedworld.gov

online ordering: http://www.ntis.gov/ordering.htm 


\section{Introduction}

To help industry offer consumers more small wind turbine systems that are certified for safety and performance, the National Renewable Energy Laboratory (NREL) and the U.S. Department of Energy (DOE) launched a Small Wind Independent Testing project in 2007. The small wind turbines will be tested to standards adopted by the International Electrotechnical Commission (IEC) and in compliance with the draft American Wind Energy Association (AWEA) standards for small wind turbine systems.

The resultant test data may be used by the Small Wind Certification Council (SWCC), a nonprofit organization formed with support from the DOE, AWEA, state energy offices, and turbine manufacturers to certify small wind turbine systems. SWCC certification is expected to commence in 2009. Test data could also be submitted to international certification agents as partial input for international certification.

Small wind turbines that are tested and certified will give consumers greater confidence that the systems they install will perform within specified wind regimes as advertised by the manufacturer.

Through a competitive solicitation, NREL selected four commercially available small wind turbine systems to test in 2008/2009 at its National Wind Technology Center near Boulder, Colorado. One of the small wind turbines selected for testing was Mariah Power's Windspire Giromill. The Windspire is a 1.2-kW vertical-axis wind turbine. The turbine tower is 9.1 meters tall, and its rotor area is $1.2 \times 6.1$ meters. The turbine has a permanent-magnet generator with a single-phase output at 120 volts AC.

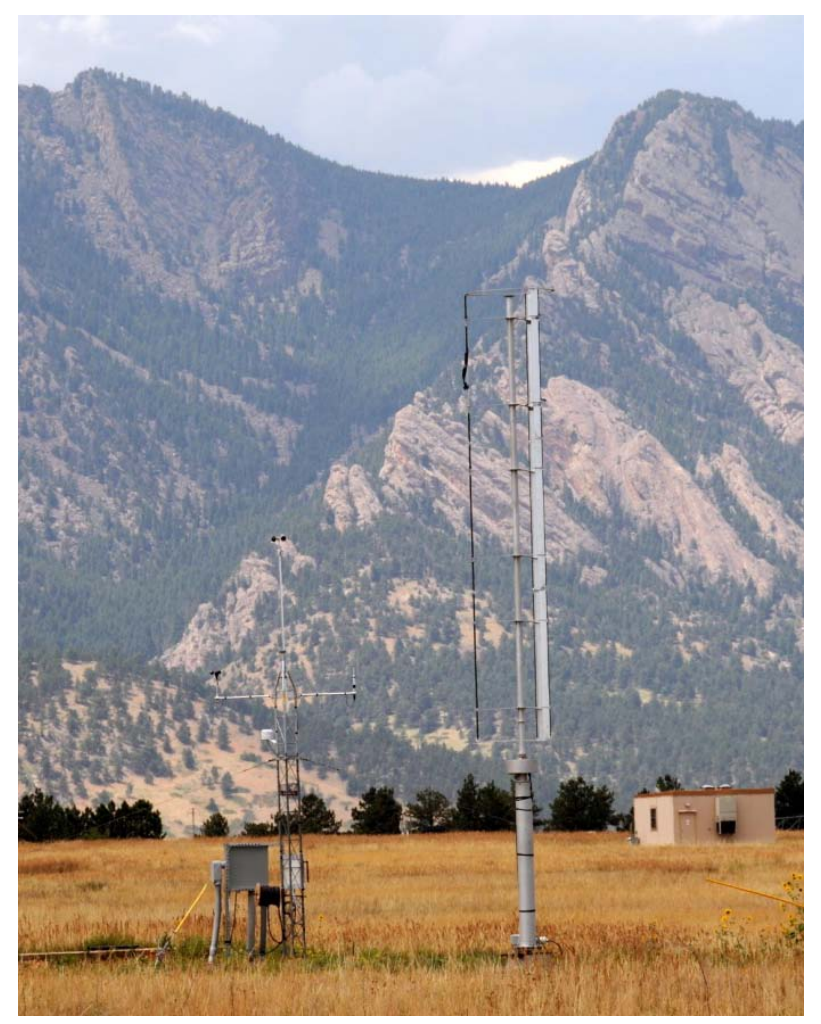

Mariah Power's 1.2-kW vertical-axis Windspire Giromill wind turbine installed for testing at the NWTC. 
This report presents a chronology of the tests conducted and a letter from Mariah Power to NREL after the tests were terminated on January 14, 2009.

\section{Mariah Windspire Project Summary}

\begin{tabular}{|c|c|}
\hline Activity & Status \\
\hline Award of Subcontract & February 5, 2008 \\
\hline $\begin{array}{l}\text { Preparation for } \\
\text { Installation }\end{array}$ & $\begin{array}{l}\text { Foundation poured: February 21, } 2008 \\
\text { Components received: March 7, } 2008 \\
\text { Inverter received: May 2, } 2008 \\
\text { Documentation received: May 8, } 2008\end{array}$ \\
\hline Turbine Installation & $\begin{array}{l}\text { Turbine Installed: March 17, } 2008 \\
\text { Inverter Installed: May 5, } 2008\end{array}$ \\
\hline Turbine Commissioning & May 15, 2008 \\
\hline \multicolumn{2}{|l|}{ Turbine $0 \& M$ and Testing } \\
\hline Safety and Function & Testing terminated $1 / 14 / 09$ \\
\hline Power Performance & Testing terminated $1 / 14 / 09$ \\
\hline $\begin{array}{l}\text { Hrs of valid data ( } 60 \\
\text { required) }\end{array}$ & 299 \\
\hline $\begin{array}{l}\text { Bins completed }(3-14 \mathrm{~m} / \mathrm{s} \\
\text { required) }\end{array}$ & $0.5-13.5$ \\
\hline Acoustic Noise & Testing terminated $1 / 14 / 09$ \\
\hline Power Quality & N/A \\
\hline Duration Test & Testing terminated $10 / 27 / 08$ \\
\hline $\begin{array}{l}\text { Months of operation ( } 6 \\
\text { required) }\end{array}$ & 4.8 \\
\hline $\begin{array}{l}\text { Hours of power production } \\
(2,500 \text { required })\end{array}$ & 831.3 \\
\hline $\begin{array}{l}\text { Hours of power production in } \\
\text { winds above } 7.2 \mathrm{~m} / \mathrm{s}(250 \\
\text { required) }\end{array}$ & 132.9 \\
\hline $\begin{array}{l}\text { Hours of power production in } \\
\text { winds above } 10.8 \mathrm{~m} / \mathrm{s} \text { ( } 25 \\
\text { required) }\end{array}$ & 12.5 \\
\hline $\begin{array}{l}\text { KWH of production, } \\
\text { cumulative }\end{array}$ & 108 \\
\hline Post-test Inspection & Not started \\
\hline Final Documentation & Not started \\
\hline Project Review Meeting & Not started \\
\hline
\end{tabular}


Windspire Cumulative Power Production from May through November 2008

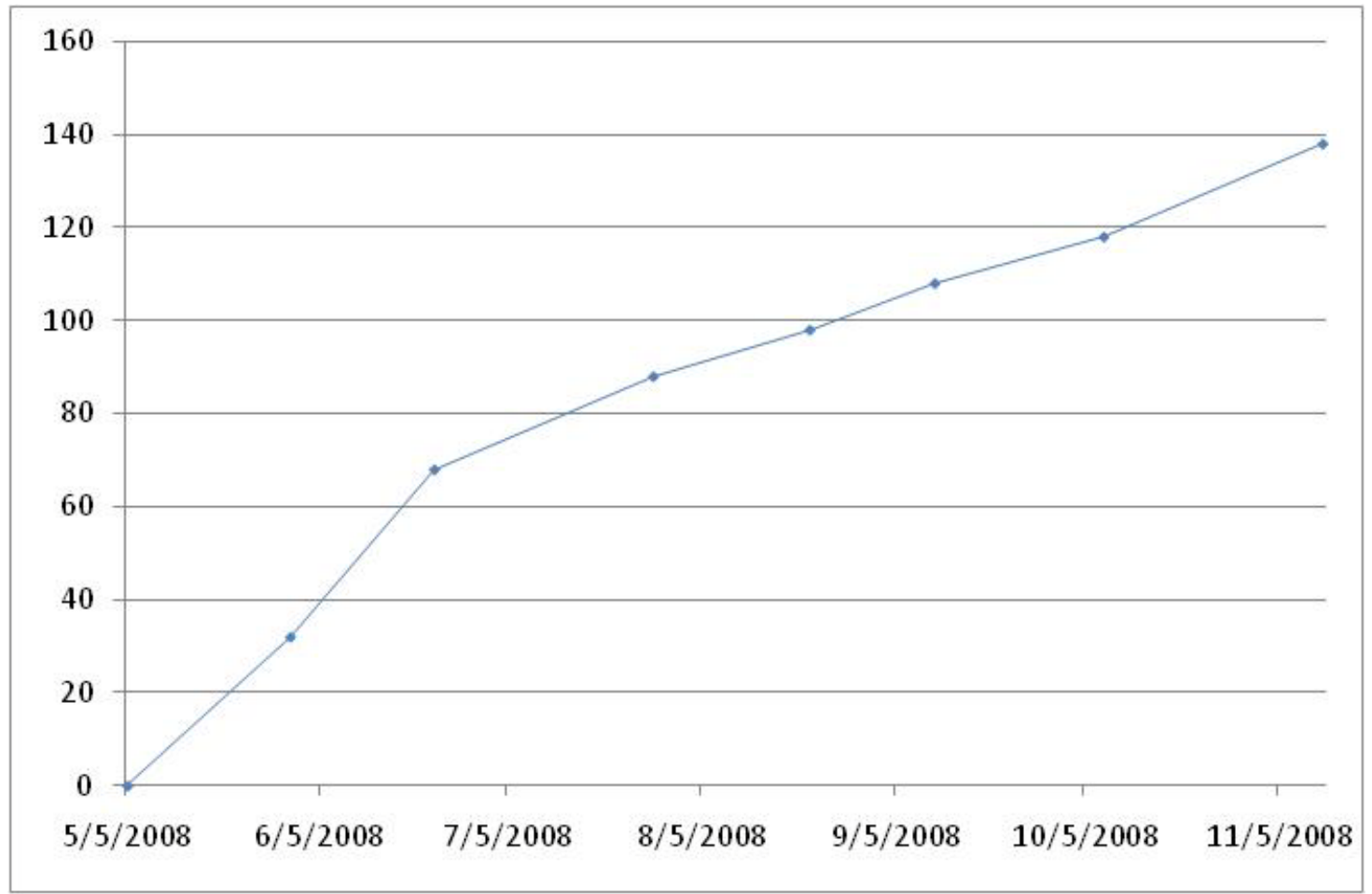

\section{Mariah Power's Windspire Wind Turbine Test Chronology}

\section{Notable events:}

5/5/08 The turbine was fully installed and operational. The turbine was installed without the inverter on March 17, 2008. The inverter was not installed until May 5, 2008.

5/9/08 Two screws were found missing at the top of the turbine where the ring attaches to the airfoil. The tower base bolts/nuts were retightened/loosened and marked to show alignment.

6/12/08 The inverter parameters were changed to increase output at rated levels from 1,000 watts to 1,100 watts.

6/23/08 The testing team found two loose bolts at the tower base. The nuts were retightened and remarked, and a small adjustment was made to vertical.

7/21/08 Routine inspection found a noise emanating from the turbine, a broken washer, loose nuts, and movement in the base tower plate. 

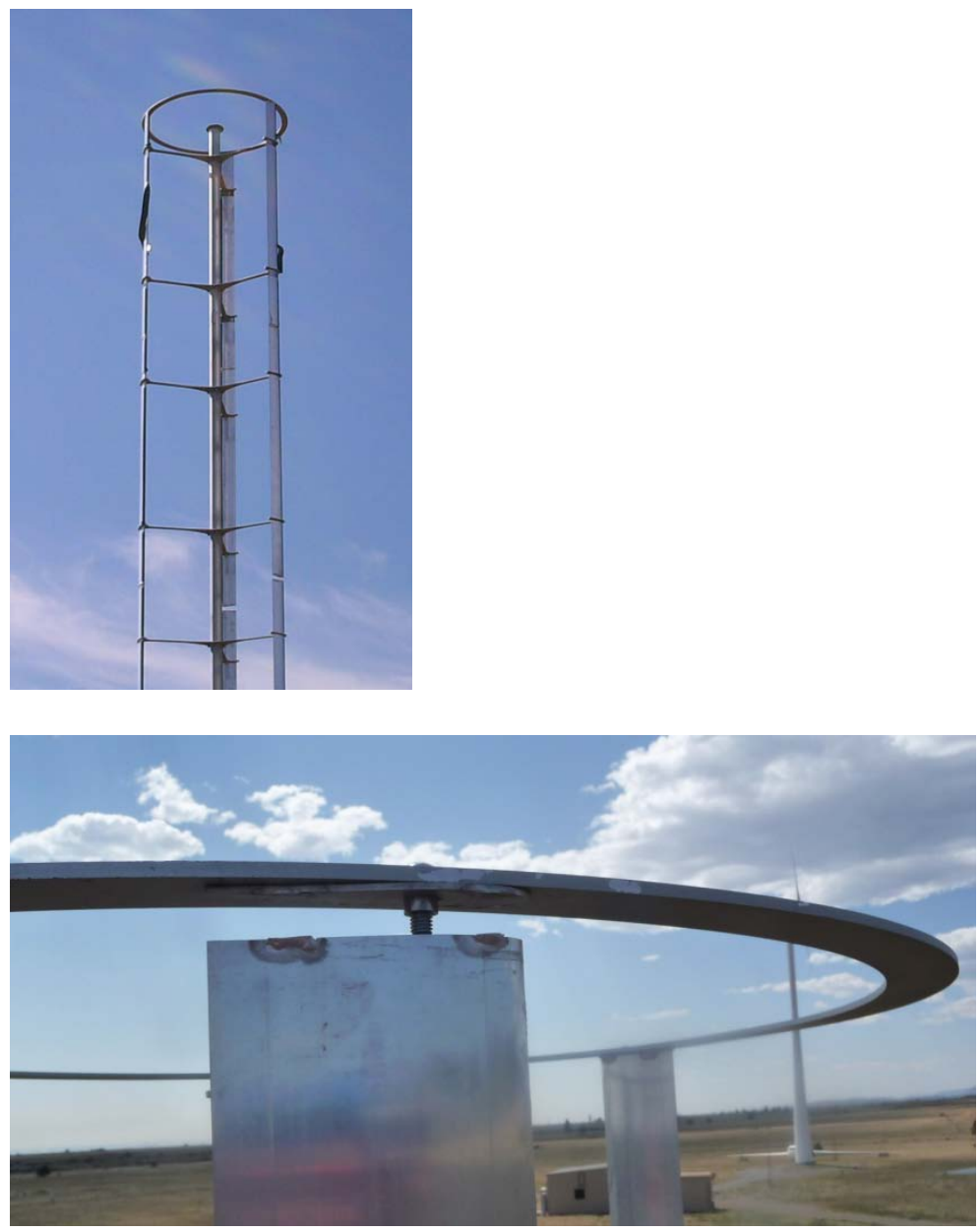

While the leading edge tape was being replaced (due to detachment), a broken weld was found at the top of the turbine and another crack was observed on a different weld. Initially, the welding was done in two spots per airfoil side. The airfoils also slid out of the struts that are supposed to clamp them. This may have caused the broken weld. The turbine was visibly wobbling and was tilted down.

8/7/08 The manufacturer was on-site to replace the airfoils and struts. This is a change that will be required for all production machines. The tower base bolts were replaced with bolts with set screws to keep bolts from loosening. The weld was improved to a continuous weld.

8/18/08 The magnetic bearing was replaced. The initial magnetic bearings did not have a dust cover and were susceptible to iron dust getting into the magnetic air gap, which can stop operation of the turbine. 


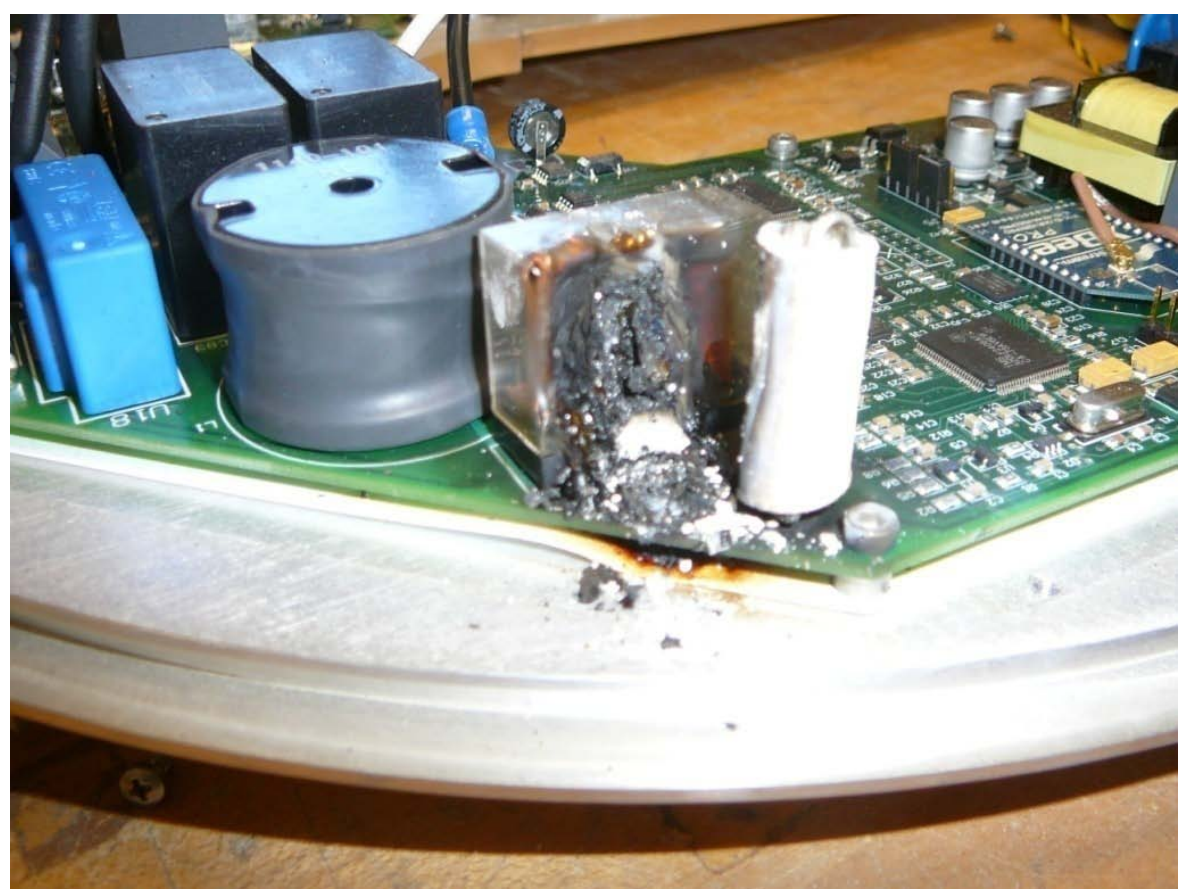

The inverter failure occurred because the set points of the inverter were set to optimize power performance. The increased performance caused the temperature to rise, and over time, caused the inverter to fail. The inverter was replaced. The set points were set for normal production.

10/7/08 The power performance test was stopped because the inverter failed. The test was not completed because the wind speed range requirement was not fulfilled/met. A new power performance test was started after the inverter was replaced.

10/14/08 Mariah informed us that: "the welding of the top shaft has not been stress relieved properly and has a heat affected zone that has reduced strength and fatigue life below the design." Based on the findings from an accelerated life test conducted at the Mariah facility, Mariah requested that the testing team stop and/or lower the turbine in winds above $40 \mathrm{mph}$ until a fix could be implemented, The fix is not expected until January 2009.

The testing team complied with Mariah's request. However, they decided to terminate duration testing because the turbine did not meet the operation requirements. The testing team decided to continue power performance and noise testing.

10/21/08 The testing team confirmed that the turbine does not shut down in high winds.

10/30/08 The testing team found three loose nuts at the base of the tower. The nuts were tightened per Mariah's direction. 
$11 / 19 / 08$

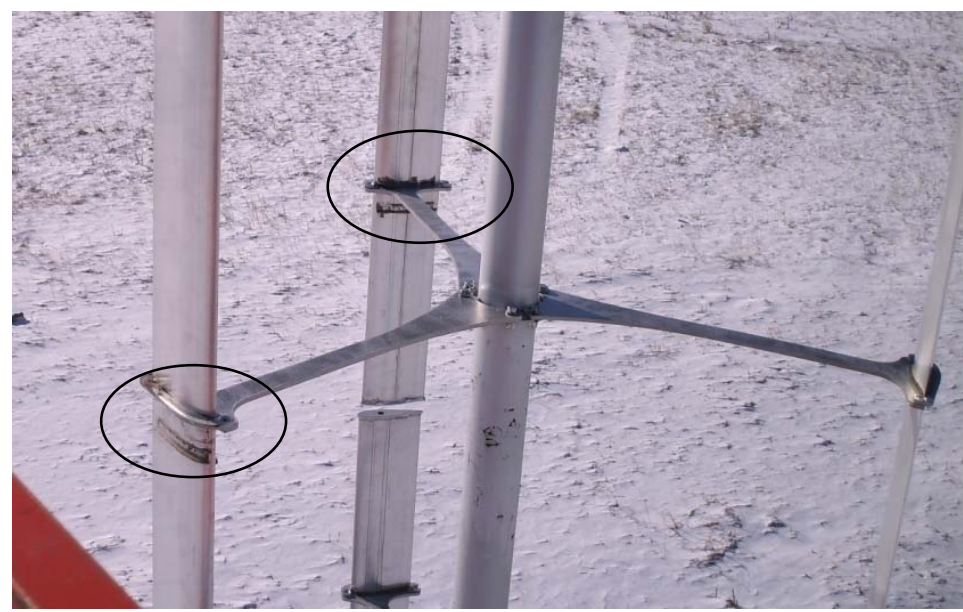

Two out of three airfoils slid down through the struts. In the picture, the black markings show where the airfoils used to be.

$12 / 16 / 08$

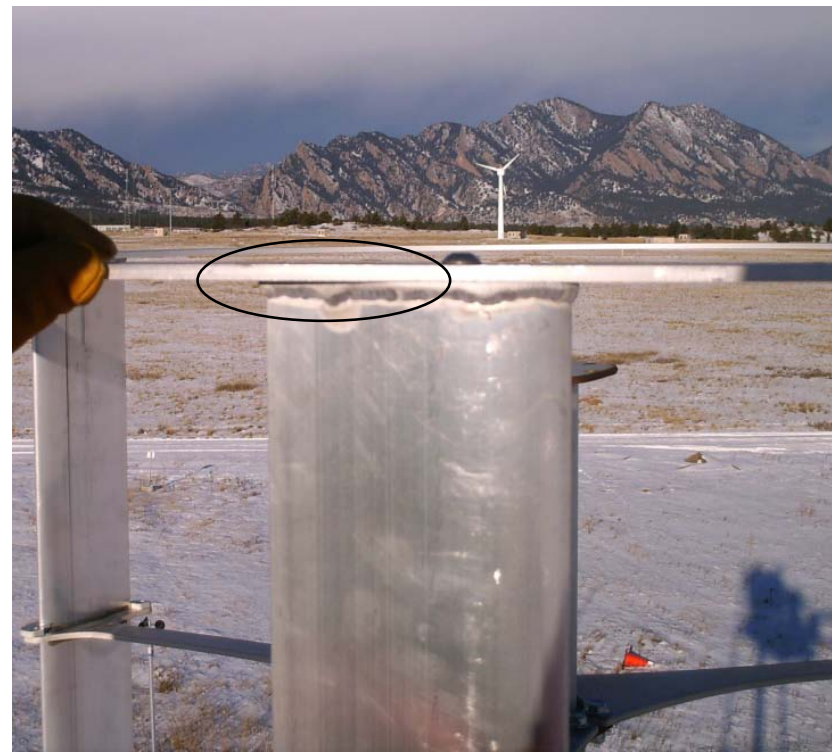

During the noise testing, a clanging sound emanated from the turbine. The testing team found two broken welds at the top of the turbine. The turbine was shut down until further notice. This photo shows one of the broken welds that caused the airfoil to separate from its end plate. However, the airfoil did not completely separate as it did in the previous occurrence. 


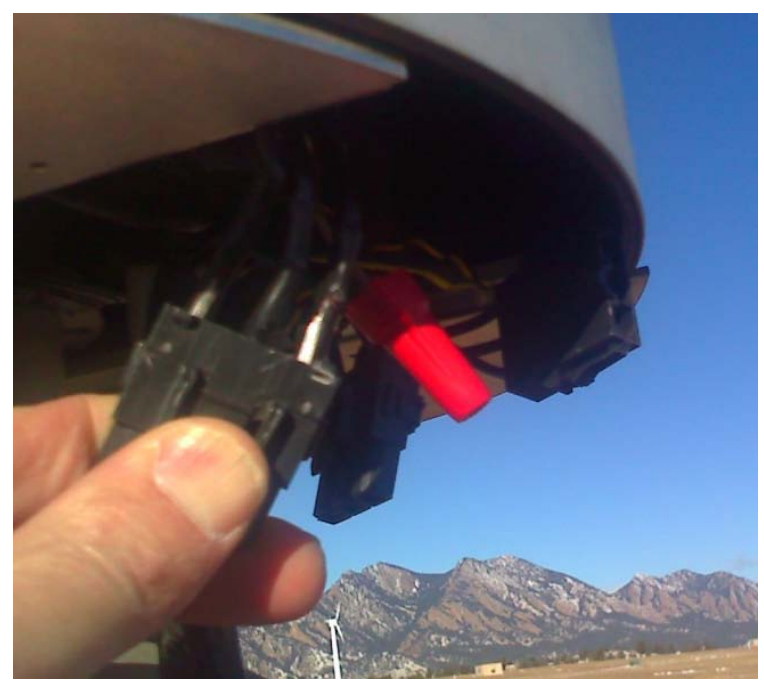

The testing team checked the turbine after it observed possible higher rotational speeds while the turbine was shut off. Measurements that were taken to check for generator continuity were varied when they should have been less than $5 \mathrm{ohms}$. The team found that two of the three wires from the generator were missing insulation and bare wire was exposed. There was no noticeable difference in resistance when force was applied while the generator was connected or not.

The turbine was lowered.

Testing

Noise data was not collected.

Update

Duration testing was terminated in October 2008.

The safety and function test was mostly completed and a report will be written with exceptions.

Power performance data collection for the two inverters were almost completed, the last required wind speed bin was not filled. A test report will be written with exceptions. 


\section{Letter from Mariah Power $4 / 29 / 09$}

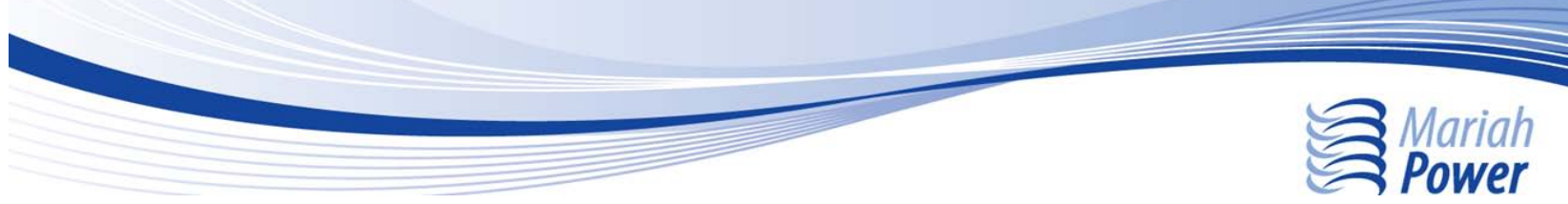

Mariah Power Response to NREL Small Wind Testing, Chronology of Events

Mariah Power thanks NREL and the staff at the Wind Technology Center for providing the opportunity to test the Windspire, and for sharing feedback in order to help us improve our product. That said, we were disappointed with the turbine component failures during the field testing at the National Renewable Energy Laboratory's Wind Technology Center (WTC) site, and the subsequent discontinuation of testing. The Windspire was a brand new product at the time testing began, and the unit provided for the test was one of our earliest production units.

In addition to testing at the WTC, Mariah Power deployed 100 units to the field as part of our 100 Unit Field Program and continued independent testing. By selecting these diverse sites, some in extreme conditions, we tried to simulate the variety of conditions in which the Windspire was designed to operate. As a result of the WTC and these other programs, we were able to identify and rectify several product design issues early in our production phase.

The problems identified at the WTC and in the field have been closely analyzed and put through a rigorous engineering change order process to remedy. Consequently, the following changes in our design and manufacturing processes have been instituted:

- New air foils replace welded end plates. These end plates are now secured with stainless steel M8 fasteners.

- The safety rings are now segmented and attached with mechanical fasteners. These replaced the butt welded rings.

- The airfoil clamping system was redesigned which provides for a more concentric gripping force. These new opposing clamps secure the airfoils from slippage.

- We have engineered stiffer and straighter shafts, and added $1 / 4$ inch thickness to the base plate. These help improve longevity and address early modal/resonance disturbances.

- The loose nuts encountered on this test unit were not encountered on any of the other field units. We believe this issue arose on the test unit due to undue stress from poor shaft straightness (see above).

- A new clamping method was developed to secure the top shaft and generator in order to eliminate fretting.

In addition, Mariah Power has introduced other product upgrades since the first units were shipped. The benefit of a complete field test program and other independent test sites is that we can identify and address potential issues quickly, and also make improvements to the existing technology. 
We were disappointed that our inverter had so many issues on the electrical side. Several factors have been changed in our inverter since UL approval, to improve reliability, power output and safety. We are working closely with ETL to incorporate these changes in our UL certification:

- Revised boost transformer to lower the internal temperature of the transformer

- Added thermal sensing to maximize wattage output while maintaining electrical integrity by shutting down when thermal limits are reached.

- Improved firmware control to better manage the power output and system control in high wind.

Finally, Mariah Power has implemented more quality control measures for its current production units. We have partnered with a top US manufacturing company, MasTech Manufacturing based in Manistee, Michigan. MasTech has manufactured for many top US and foreign car companies and is well known for its expertise in meeting stringent quality controls. We have put in place critical components to our new manufacturing processes:

- Hired AWS certified welders.

- Hired an ASQ certified quality engineer to manage the quality process at Mastech Manufacturing.

- Combined wrought multi-piece components into steel and aluminum castings.

- Put holding fixtures for component fabrication in place to provide consistent machining of the parts.

- Use plug and ring gauges for functional inspection of critical dimensions to ensure consistency of systems.

We are continuing and expanding our own third party testing programs to ensure we integrate testing methodologies and results into our own programs. We look forward to the upcoming AWEA standards for small wind turbines and testing against these requirements once ratified.

Respectfully Yours,

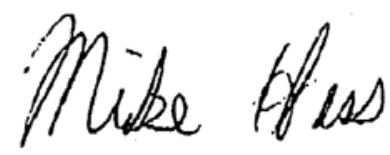

Mike Hess, on behalf of the entire Mariah Power team

(Signed for Mike Hess with his permission) 


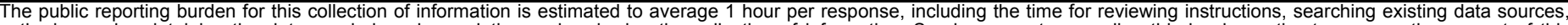

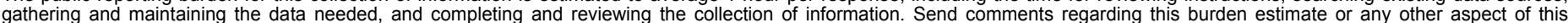

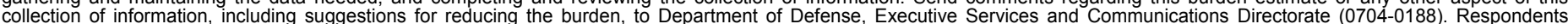

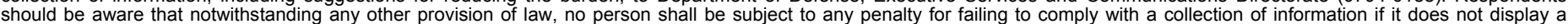

should be aware that notwithstanding

PLEASE DO NOT RETURN YOUR FORM TO THE ABOVE ORGANIZATION.
1. REPORT DATE (DD-MM-YYYY) June 2009
4. TITLE AND SUBTITLE
NREL Small WInd Turbine Test Project: Mariah Power's Windspire
Wind Turbine Test Chronology

\author{
2. REPORT TYPE \\ Technical Report
}

3. DATES COVERED (From - To)

5a. CONTRACT NUMBER

DE-AC36-08-GO28308

5b. GRANT NUMBER

5c. PROGRAM ELEMENT NUMBER

5d. PROJECT NUMBER

NREL/TP-500-45552

5e. TASK NUMBER

WER94501

5f. WORK UNIT NUMBER
7. PERFORMING ORGANIZATION NAME(S) AND ADDRESS(ES)

National Renewable Energy Laboratory

1617 Cole Blvd.

Golden, CO 80401-3393

\section{PERFORMING ORGANIZATION REPORT NUMBER \\ NREL/TP-500-45552}

9. SPONSORING/MONITORING AGENCY NAME(S) AND ADDRESS(ES)

10. SPONSOR/MONITOR'S ACRONYM(S) NREL

11. SPONSORING/MONITORING AGENCY REPORT NUMBER

12. DISTRIBUTION AVAILABILITY STATEMENT

National Technical Information Service

U.S. Department of Commerce

5285 Port Royal Road

Springfield, VA 22161

13. SUPPLEMENTARY NOTES

14. ABSTRACT (Maximum 200 Words)

This report presents a chronology of tests conducted at NREL's National Wind Technology Center on Mariah Power's

Windspire 1.2-kW wind turbine and a letter of response from Mariah Power.

\section{SUBJECT TERMS}

Small wind independent testing; Mariah Power; Windspire Giromill vertical-axis wind turbine; small wind

\begin{tabular}{|c|c|c|}
\hline \multicolumn{3}{|c|}{ 16. SECURITY CLASSIFICATION OF: } \\
\hline $\begin{array}{l}\text { a. REPORT } \\
\text { Unclassified }\end{array}$ & $\begin{array}{l}\text { b. ABSTRACT } \\
\text { Unclassified }\end{array}$ & $\begin{array}{l}\text { c. THIS PAGE } \\
\text { Unclassified }\end{array}$ \\
\hline
\end{tabular}

\begin{tabular}{l|l} 
17. LIMITATION & 18. \\
OF ABSTRACT & OF PAGES \\
UL &
\end{tabular}

19a. NAME OF RESPONSIBLE PERSON

19b. TELEPHONE NUMBER (Include area code) 